\title{
The perceived impact of performance appraisal on the performance of small-to-medium-sized enterprises in Zimbabwe
}

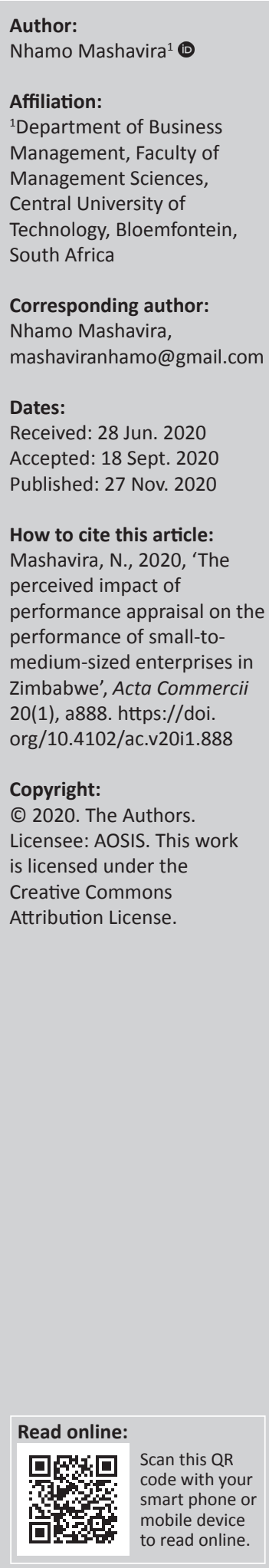

Orientation: The increasing focus on human resource management (HRM) and performance appraisal, in particular, in small- to- medium-sized enterprises (SMEs) is a comparatively recent phenomenon. Unfortunately, much of our knowledge of traditional HRM topics in large corporations may not necessarily apply in the enterprises.

Research purpose: This study purposed to examine whether performance appraisal had an impact on SMEs' performance measured by return on investment (ROI) and innovation in Harare Province, Zimbabwe.

Motivation for the study: Small- to- medium-sized enterprises are becoming the dominant form of business in terms of the socio-economic development of countries worldwide, in areas such as gross domestic product and employment. In view of this, a systematic collection of information about employees in the enterprises, which forms the bedrock of all human resource (HR) practice, can be done through performance appraisal. Unfortunately, performance appraisal in SMEs has not received adequate research attention.

Research design, approach and method: The study employed an ex post facto correlational design that adopted a purely quantitative approach. A total of 106 owners or managers took part in the survey. A self-constructed structured questionnaire was used to collect data. The Statistical Package for Social Sciences (SPSS) version 20 was used for both descriptive and inferential statistics.

Main findings: Most owner or managers made use of the 360-degree performance appraisal method. The study established that very weak and statistically insignificant relationships existed between performance appraisal and firm performance measured by both ROI and innovation.

Practical/managerial implications: It is recommended that the government through the relevant ministries and agencies should consider more financial inducements, tax relief for start-ups and additional grants to support investments in new technology, and more training for owner or managers. This could, amongst other things, go a long way in assisting them to acquire sufficient information technology infrastructure for effective implementation of performance appraisals.

Contribution/value-add: The current study is one of the very few, if any, that sheds light on the nexus between HRM and performance appraisal in particular and the performance of SMEs in the country. Unlike most studies, the current study adopted a hybrid approach in the measurement of performance, making use of both objective and subjective measures.

Keywords: performance appraisal; performance; small-to-medium, performance management, Zimbabwe.

\section{Introduction}

Firm performance is often attributed to factors such as inadequate government support, or managerial competencies, ignoring other factors such as effective performance management. Performance management is a variety of integrated activities executed by a firm to continuously augment performance by setting goals, analysing results and remunerating the performance of employees (DeNisi 2011; Gravina \& Siers 2011). Performance management (particularly use of the performance appraisal tool) is suggested in literature as pivotal in supporting firm growth (Bititci, Cocca \& Ates 2015), especially amongst small- to medium-sized enterprises (SMEs). The terms 'performance appraisal' and 'performance management' are commonly confused terms because they both involve the evaluation of employees, leading them to be used interchangeably (McMahon 2013). Even with this confusion, it can be argued that performance management is 
more expansive than performance appraisal, as the former tends to be linked with developments in areas like coaching, competency-based appraisal, 360-degree feedback, performance pay and (of late) employee engagement (McMahon 2013). That is, unlike performance appraisal, performance management is more strategic.

'Despite being the most substantial development in the area of human resource management, performance management had not received much empirical attention amongst entrepreneurial organisations' (Sidhardth 2011; Wickramasinghe 2016). Abduli (2013) argues that the lack of performance management practices amongst many small businesses is because of the less importance given to human resource (HR) functions, cost of establishing a full-fledged HR unit and size of the business, amongst others. This resonates with prior studies (Harney \& Nolan 2014; Melo \& Machado 2014), which established that recently human resource management (HRM) has been seen as unsuitable for smaller firms and, as a result, limited research on the practices within them has been documented. Contrarily, Arafat and Ahmad (2012), however, note that there has been resurgence of interest in managing employee performance amongst SMEs in emerging economies because of government support of small businesses to alleviate unemployment.

The few studies available on performance management in SMEs in general (Wijetunge 2014; Zheng, O'Neill \& Morrison 2009) suggest that SMEs face difficulties in the practice of performance management. Yet, properly done, performance management, through its evaluation tool - performance appraisal - could help solve problems, identify cause-effect associations and the subsequent learning, grounded on established causation (Kasperskaya \& Tayles 2013). Performance appraisals would go a long way to provide data about personnel (which is the bedrock of all HR practice) for use in activities such as salary administration, layoffs, retention-termination, promotions and recognition of individual performance (Noe et al. 2015). However, the increasing competitive environment, the chances of growing in size, emphasis on quality, the increased interest in continuous improvement and the remarkable developments in information and communication technologies within globalising economies are the most significant milestones that call for the implementation of adaptable performance management practices (Garengo et al. 2005; Taticchi, Tonelli \& Cagnazzo 2010) in SMEs. In addition, Biron, Farndale and Paauwe (2011) suggest that performance management amongst SMEs can result in better financial performance, increased worker productivity and more enthused employees. This evidence provides a scope for further extending research on performance appraisal in SMEs.

\section{Problem background}

Small- to- medium-sized enterprises are the dominant form of business firms in developed, transitional and developing economies - where they play an essential role in the economy. For instance, Japan has the biggest share of SMEs amongst the developed countries, occupying more than $99 \%$ of total enterprises (Economist Intelligence Unit 2010). In emerging economies, the SME sector contributes up to $45 \%$ of total employment and 33\% of gross domestic product (OECD 2017). Micro enterprises accounted for over $80 \%$ of all jobs in 2004 (Luebker 2008), with up to $70 \%$ of Zimbabweans depending on them for their livelihoods (Ministry of Finance 2011). The stagnation and harsh economic environment affecting Zimbabwe has encouraged massive informalisation of the economy, resulting in the creation of new jobs by survivalist entrepreneurs. About $47 \%$ of the economically active populations of the urban areas derive their income from self-employment (Kamoyo, Muranda \& Mavhima 2014). Accordingly, it is sensible that the Zimbabwean government promotes the SME-based economy as its preferred economic model - because it aligns with the objectives of its indigenisation programme (Southern Eye 2014).

In spite of the role SMEs play in modern economies, it is unfortunate that HRM has been seen as inappropriate for smaller firms and consequently little research on the practices within them has been documented by 2001 (Reid \& Adams 2001). As far back as 1995, Jones, Morris and Rockmore observed that performance appraisal and compensation, in particular, are the pivotal mechanisms for fostering entrepreneurship, but interestingly, by 2003, minimal work has been done on performance management in entrepreneurial organisations (De Kok, Thurik \& Uhlaner 2003). Umer (2012) also admits that the increasing focus on HRM in SMEs is a comparatively recent phenomenon and that scholars seem to be realising its importance in SMEs.

Yet, much of our knowledge of traditional HRM topics in large firms may not necessarily apply in small or emergent ventures. In small firms where resources are likely to be scarce, there may be a very small number of formal HR departments or professionals and an increased reluctance to engage in costly or restrictive practices (Cardon \& Stevens 2004:298). Therefore, performance management within the context of SMEs requires an appreciation of those SME characteristics that influence the design and implementation of performance measurement (Ates et al. 2013; Garengo et al. 2005). Unlike their other counterparts, larger companies have the resources and people available to implement and perform state-of-the-art HRM policies and practices, creating more exciting research playgrounds (Van Riemsdijk, Bondarouk \& Knol 2005). Worse still, unlike their counterparts operating in developed countries, SMEs in transition economies operate under weak market institutions and infrastructures (Hoskisson et al. 2000; Peng 2001). Moreover, owners or managers of these nascent SMEs may not be very familiar with the formal HR systems that have been used in developed countries (Nguyen \& Bryant 2004).

According to Dessler (2013), managing HRs in small firms is different, because of their size, priorities, informality and the nature of the entrepreneur. Human resource management tends to be more informal in smaller firms and such 
informality is not just because of a lack of resources. It is also partly a survival strategy, because entrepreneurs must be able to quickly react to changes in competitive conditions (Dessler 2013). The need for SMEs to quickly adapt to competition often means handling matters like recruitment, appraisals and time off, on an informal, reactive basis and with a short time horizon (Dessler 2013). Most studies researching HR formality conclude that in SMEs, in general, HRM is informal, intuitive and ad hoc (Umer 2012). The optimality of so doing remains clouded in controversy (Umer 2012). This provides a scope for further extending reach on performance appraisal in SMEs.

Interestingly, results from a study done in South Africa by Neneh and Van Zyl (2012) revealed that amongst other business practices, HRM and particularly performance management have a significant and positive relationship with the performance of SMEs (Neneh \& Van Zyl 2012). Whilst minimal work has been done on performance management in entrepreneurial firms (Wickramasinghe 2016), very few, if any, research has explored how performance appraisal is done in the two types of enterprises within the context of Harare Province, Zimbabwe. The current study, amongst other things, seeks to close such a gap in literature.

\section{Research purpose and objectives}

Extant literature is replete with studies on the extent to which HRM can be used to augment business performance (Foss et al. 2015; Saha, Gregar \& Saha 2017); yet, with few exceptions, research has progressed slower in SMEs than in other businesses (Kim \& Gao 2010). Obasan (2012) admits that HR practices in these enterprises have not received significant attention and that limited research on HRM practices in them has been conducted. Whilst Patel and Cardon (2010) acknowledge that HR practices positively affect firm performance, there is a need for similar evidence to be confirmed for entrepreneurial ventures. One HRM practice that remains a lacuna in small business research is performance management and how it relates to business performance (Memon, Rohra \& Lal 2010). The same could be said of performance appraisal (Heinicke 2018). Forth and Bryson (2018) found out that although SMEs in Britain were less likely to use formal management practices than their other counterparts, such practices showed demonstrable benefits for those enterprises using them, helping firms to grow and increase their productivity. However, a study in medium-sized enterprises in Sri Lanka by Wickramasinghe (2016) found that performance appraisal in the enterprises under study failed to influence innovation possibly because of informality, goals not aligned with company, team and individual objectives and inefficient employee performance feedback systems. Sheer lack of managerial capacity and culture in these firms may result in managerial tools and techniques (such as performance appraisal) being perceived as of little benefit to the firm (Pekkola, Saunila \& Rantanen 2016). Frequently, employees occupy different positions at the same time, organisation structures are flat, and although the owner or manager oversees both operational and managerial functions, managerial activities are usually neglected (Barisic \& Bozicevic 2013). Based on the aforementioned evidence, the current study aims at examining whether performance appraisal has an impact on SMEs' performance in Zimbabwe as measured by return on investment (ROI) and both product and process innovation (referred to as innovation in this study), and it is guided by the following objectives:

- To find out performance appraisal methods used by owner or managers in SMEs in Zimbabwe.

- To determine the performance of SMEs in Zimbabwe as measured by ROI and innovation.

- To assess the impact of performance appraisal on the enterprises' performance.

\section{Literature review Evolution of performance management}

Performance management has been the most significant development in the sphere of HRs recently (Panda 2011). But like many other HRM innovations, it is an American import whose origins are controversial (McMahon 2013). Sidhardth (2011) dates its origins back to the creation account in the Book of Genesis. The evaluation of performance can be traced back to the 6th day after creation of the universe: 'God saw all that he had made, and it was very good' (Gn 1:31). God had to evaluate his creative genius after 6 days of continuous labour. However, as a scientific management concept, performance management was developed from a reward system on an assignment basis for employees (Taylor 1911), with human labour being regarded as one amongst many factors of production that could be managed scientifically to increase productivity (Khahan 2016). Performance management was meant to do a retroactive evaluation of an employee's output for individual performance improvement (Khahan 2016).

Juneja (2019) traces the origins of performance management to the early 1960s, when performance appraisal systems were still common and employee service records were maintained for both controlling employee behaviours and providing extensive information on employee performance. As a result of experiments and extensive study, the philosophy of performance appraisal has gone through remarkable modifications including the terminology used (Sidhardth 2011). According to Sidhardth (2011), the progression is as follows: Merit rating in the 1950s to 1960s; management by objectives and behaviourally anchored rating scale in the 1960s to 1970s; result-oriented performance appraisal in the 1970s and performance management from the mid-1980s onwards. Noteworthy are the developments that started in the mid1970s in India as great business moguls like Larsen and Toubro, followed by the State Bank of India, amongst others, introduced noticeable reforms in this area (Juneja 2019). This phase saw an appraisal process that was development-driven, 
performance- or target-based, methodical, open and participative rather than secretive (Juneja 2019).

According to DeNisi and Murphy (2017), there was a remarkable rise in studies on cognitive procedures in appraising performance in the 1980s, bringing researchers' attention to the significance of these processes. Excellent reviews by Ilgen, Barnes-Farrell and McKellin (1993), of cognitive research on performance appraisal, were done. However, beginning in 1990, there was a decline in studies of cognitive processes in performance appraisal, indicating, partly, a growing concern about the importance of this work to performance appraisal practices in organisations (Ilgen et al. 1993). It is the realisation in the late 1980s that a more comprehensive system to manage and reward performance was needed that led to the development of the method of managing performance in the United Kingdom (UK) and the United States of America (USA), much earlier than in Australia (Sidhardth 2011).

It was also in the 1980s in the United Kingdom and United States of America that decision support systems were adopted in performance management for purposes of storing, summarising and examining information used in an organisation's decision-making (Khahan 2016). Subsequently, the 1990s saw business information being integrated more into computer-based business intelligent systems developed to accompany performance management decisions. The evolution of performance management as an upcoming HRM model, therefore, reveals a change of emphasis in organisations - away from command and control towards the facilitation model of leadership (Sidhardth 2011). Although performance management systems are still evolving, the last phase, according to Juneja (2019), was marked by a maturity in the approach of handling people's issues, with more emphasis given to planning, development and improvement, culture building, quality circles and team appraisals than to evaluating the quality of rating data by way of evaluating the validity, reliability or accuracy of performance ratings (DeNisi \& Murphy 2017).

\section{Performance management in small- to medium- sized enterprises}

Regarding the use of performance management in SMEs, Cardon and Stevens (2004) observed that minimal work on performance management had been done in entrepreneurial organisations. Moreover, no direct study of performance management in small firms had been done, except for the study by Cardy (2003). The authors attribute this to the rarity of formal procedures in small firms for evaluating employee performance. The relative lack of concern by small business owners on downstream management issues, particularly those associated with negative consequences such as employee underperformance or the business having to lay off workers, could be attributed to this vacuum in scholarship (Cardon \& Stevens 2004). However, Harney and Nolan (2014) bemoan that research on performance management in SMEs has generally pursued one of two broad approaches. The first approach tends to 'denature' SMEs, by judging them as being indistinct from larger organisations through taking sophisticated people management practices prevalent in larger companies and assessing their impact on performance in SMEs. Such an approach resonates with the assertion by Melo and Machado (2014) that studies of HRM in general within SMEs give emphasis to practices used in big firms, but adapted to the size, culture and resources of small firms. By contrast, the second approach, which tends to acknowledge SME 'specificity', explores how unique HRM challenges and practices, such as performance appraisal, may be experienced, because of the dynamics of the SME context (Harney \& Nolan 2014). The respective contexts of either smallness or newness may each yield specific HR challenges.

\section{Performance appraisal in small- to medium-sized enterprises}

Performance appraisal is also called employee rating, performance review, employee evaluation, results appraisal or performance evaluation (Mathis \& Jackson 2005). Appraisal is the evaluation of worth, quality or merit (Toppo \& Prusty 2012). In the context of work, performance appraisal is a systematic assessment of employees by supervisors familiar with their performance (Prasad 2006). It is one of the oldest and universal management practice (Tripathi 2006).

Performance appraisal has become an important link in the whole process of performance management, since it has, in recent times, been integrated into performance management systems. Research focused on understanding the HRM practices and particularly performance management in SMEs has not been fully explored by academics and practitioners (Nzonzo \& Matashu 2014:74). Wood and Pereira (2014) considered performance appraisal in an SME operating in the building and manufacturing sector, and established that there was no formal process of 360-degree feedback system within the enterprise, although managers provided employees with feedback from colleagues and customers. Employees in the SME regarded the performance appraisal process as a mere tick-box exercise because of a lack of informal feedback in addition to feedback provided by the formal performance evaluation process (Wood \& Pereira 2014). Regarding 360-degree, employees suggested that managers should not necessarily focus on implementing a 360-degree system, but should concentrate on providing good quality feedback as an effective performance improvement tool (Wood \& Pereira 2014). These results corroborate those from a study by Na-Nan, Chaiprasit and Pukkeeree (2017). The study carried out amongst SMEs in high-growth and high-impact sectors in Thailand established that within the SMEs, performance management was uncharacteristically dogged by a lack of employee participation, ineffective communication, unclear goal setting and unfair evaluation (Na-Nan et al. 2017). Yet, avoiding regular or formal discussions about individual performance expectations and results brings a lot of uncertainty about fairness when raises and bonuses are distributed to family members (Dashew 2007). 
A study by Aleem and Rahman (2018) examined the influence of HR practices on the perceived financial performance of listed SMEs in Karachi, Pakistan. The investigation established a positive and strong association between HRM practices and the enterprises' perceived financial performance. Even though the study considered a bundle of HR practices, it confirmed that training and performance appraisal had the most positive and strongest association with a firm's perceived business performance. Results of this study confirmed findings by past studies (Jamsari, Mahmood \& Raghavan 2017; Nongmaithem \& Kassa 2016) that when employees get a fair performance feedback and firms invest in training, the two would result in better and increased business performance. Whilst every HR function is critical to performance management, performance appraisal and training play a very significant role (HR Tool 2011).

In order to validate the aforesaid evidence within the context of SMEs in Harare Province, Zimbabwe, the following hypotheses were proffered:

$H_{1}$ : There is a statistically significant relationship between performance appraisal and SME performance measured by innovation.

$\mathrm{H}_{2}$ : There is a statistically significant relationship between performance appraisal and SME performance measured by ROI.

Oduro-Nyarko (2013) found out that managers in small- and medium-sized hotels in the Ayawaso Central Sub-metro of the Greater Accra region of Ghana used traditional HRM practices that are predominantly top-down in nature. OduroNyarko (2013) also observed that in their quest for costeffectiveness, SMEs in the hotel industry mainly use traditional HRM practices that were less time consuming, instead of the available sophisticated performance management practices used by other organisations. The study found out that $53.3 \%$ of the managers did not use information on performance appraisal for the promotion of employees. However, most of the managers assessed the performance of their employees on a daily basis as a way of encouraging their consistently low-performing employees to improve upon their performance (Oduro-Nyarko 2013).

\section{Measuring small- to medium-sized enterprises performance}

Measuring business performance in SMEs is necessary if high standards of performance are to be attained. As observed by Cocca and Alberti (2010), what gets measured gets attention. The implication is that businesses can take corrective actions on any anomalies only after a measurement of progress on given activities has been done (Sandada 2012). That will make businesses gain competitive advantages as they continuously react and adapt to external changes (Cocca \& Alberti 2010). Research gives numerous benefits behind measuring performance in firms, but Ogiogio (2005) sums it up by acknowledging that performance measurement aids organisations measure, monitor and evaluate performance, as well as define and set benchmarks that help in the implementation of performance improvement plans.
Small business performance can be measured using financial and non-financial criteria, although the former has been given more attention in literature (Sandada \& Mangwandi 2015). Sandada (2012) realises that the terms objective, financial and quantitative measures are used interchangeably whilst qualitative or non-financial measures may be used to refer to subjective measures. The shortfalls of traditional financially based performance measurement frameworks and the introduction of non-financial measures have sparked considerable amount of research over the past 15 years (Bassioni, Price \& Hassan 2005). Because some businesses have no interest in growth, financial gain may not be their primary or only motivation; therefore, there must be other non-financial criteria to measure the success of such firms. As measuring profitability (e.g. profits, revenues, ROI) is subject to manipulations, a possible way forward is to supplement such measures with non-financial measures. Although financial measures are objective, simple and easy to understand and compute, in most cases, they suffer from being historical and are not readily available in the public domain (Chong 2008). Furthermore, as objective criteria in the financial statements of a firm can be flawed, relevant objective data could be lacking and that difficulties could be encountered in reaching objective data; it may be necessary to rely on subjective data obtained from participants (Zehir \& Acar 2005). In view of the above, the current study adopted a hybrid approach that used both a financial (ROI) and a nonfinancial measure (Innovation) in measuring the performance of SMEs.

\section{Research methodology Research design}

The current study employed a correlational design, specifically the ex post facto (literally meaning 'after the fact' or 'retrospectively' design). Correlational studies are regarded as ex post facto studies (Simon \& Goes 2011). A correlational design attempts to describe relationships, rather than explain them (Gravetter \& Forzano 2016). Although a correlational research does not imply causality, it serves two functions (De Vos et al. 2011). Firstly, it allows for predictions to be made even though one may not have an idea why a relationship exists. For instance, it may be established that a strong positive relationship exists between performance appraisal and firm performance, but one's dilemma would be on why such a relationship exists. Secondly, correlational research provides data that is either consistent or inconsistent with scientific theory (De Vos et al. 2011).

\section{Research approach}

Hughes (2006) posits that the two general approaches quantitative and qualitative - are strongly associated with objectivity and subjectivity, respectively. The current study adopted a quantitative approach as the social phenomena under study were regarded as objective in nature. Quantitative research relies more on deductive reasoning (moving from the general to the specific), 
beginning with certain premises (like theories and hypotheses), and then making logical conclusions from them (De Vos et al. 2011).

\section{Research participants}

Owner or managers in Harare Province were chosen because the province had a higher concentration of SMEs (Madzivanzira 2011). However, because of lack of a comprehensive database of SMEs in the province, it became impracticable to come up with a comprehensive sampling frame of the enterprises. As a result, convenience sampling had to be used. Convenience sampling is the most used method in the behavioural sciences, and examples of it, include television surveys or people in the street who are stopped for interviews (Gravetter \& Forzano 2016). Convenience sampling was considered to be the most appropriate for acquiring a large sample to meet the minimum threshold of data required, given the limited amount of time to complete the research and the lack of knowledge on the actual population size or list (Creswell 2012). However, in order to mitigate the weaknesses associated with sampling conveniently, the researcher had to ensure that samples were reasonably large to increase their statistical power. A total of 106 questionnaires were completed.

\section{Research instruments}

The researcher used a self-constructed structured questionnaire to collect data. The self-constructed items measured performance appraisal methods used, ROI and innovation. The items had to be pre-coded for statistical analysis. Section A on biographical information contained dichotomous questions, closed questions and open-ended questions demanding at most two-phrased answers. The rest of the questionnaire contained five-point Likert-scaled questions, where respondents showed the extent to which they either agreed or their attitude concerning the extent to which a certain phenomenon was used (De Vos et al. 2011). Fieldworkers only availed themselves when clarifications were needed.

\section{Ensuring reliability and validity}

Reliability enables the researcher to estimate error and the two have a reciprocal relationship: the larger the reliability, the smaller the error, and conversely, the smaller the reliability, the larger the error (Punch 2005). Cohen, Manion and Morrison (2011) identified three principal types of reliability, namely, stability, equivalence and internal consistency. Reliability as stability implies that a reliable research instrument will yield similar data from similar respondents over time. Reliability as equivalence means that an equivalent form of an instrument devised will yield similar results (e.g. the pre-test and post-test in an experimental model of evaluation); and as internal consistency, reliability demonstrates that the instrument be run once only through the split-half method (Cohen et al. 2011).
Cronbach's alpha measured split-half reliability by estimating the average correlation that would be obtained by considering every possible way to split the test in half (Gravetter \& Forzano 2016). It produces values between 0 and 1.00, and a higher value shows a better degree of internal consistency or reliability. A value above 0.7 suggests a good reliability (Hair et al. 2014). Table 1 shows the reliability statistics results.

A Cronbach's alpha of $0.816(\alpha=0.816)$ is a good reliability measure. It means that all the items were internally consistent and reliable.

The questionnaire was subjected to pilot testing on SMEs in a different sector before administering it to research participants. Pilot testing allowed for amendments deemed essential in order to increase the instrument's validity as well as reliability (De Vos et al. 2011; Neuman 2011). Pilot testing provided some idea on the questionnaire's face validity: that is, whether the questionnaire appeared to make sense (Saunders, Lewis \& Thornhill 2009). Responses from pilot testing provided the researcher with an idea of the reliability and suitability of the items allowing for necessary amendments to be done.

\section{Research procedure}

The services of trained former HRM students of Great Zimbabwe University were enlisted as research assistants to hand-deliver questionnaires. This raised response rates as a result of the personal contact and because research assistants did not interrupt respondents during working hours (De Vos et al. 2011). Data for 2015 and 2016 were collected.

\section{Statistical analysis}

The Statistical Package for Social Sciences (SPSS) version 20 was used for both descriptive and inferential statistics. Bivariate correlation analysis in the form of Spearman's correlation coefficient was used to examine the nature and strength of the relationship between performance appraisal and firm performance.

\section{Ethical considerations}

The researcher had to seek for clearance from the Faculty of Management Sciences Research Ethics committee. Respondents' consent before participation was sought. The questionnaire cover page allowed for participants to withdraw at any time. Respondents were also made aware of the purposes the data would be used for. To ensure privacy, respondents were not identified with their names on both the collection of data and publication of research results. In order to ensure confidentiality, data was stored in lockable cabinets and all identifying information was removed.

TABLE 1: Reliability statistics results.

Cronbach's alpha Cronbach's alpha based on standardised items No. of items
\begin{tabular}{lll}
\hline 0.816 & 0.805 & 22 \\
\hline
\end{tabular} 


\section{Research findings Performance appraisal methods}

Table 2 shows the mean, median and standard deviation of responses on the extent to which owner or managers used the listed performance appraisal methods at their business.

Table 2 shows that most owner or managers made use of the 360 -degree method shown by a mean of 4.00 on a Likert scale ranged from 1 Strongly Disagree to 5 Strongly Agree. The other performance appraisal methods were not as popular possibly because of the formality and complexity required in their execution As has been observed by Dessler (2013), HRM tends to be more informal in smaller firms as a survival strategy. The other reason why the 360-degree method was popular could be because of the spectrum of performancerelated feedback it proffers more than old assessment techniques (Mckenna \& Beech 2013).

\section{Firm performance}

Table 3 shows the performance of SMEs as measured by both ROI and innovation.

SME, small- to- medium-sized enterprises; ROI, return on investment.

Innovation and ROI were each measured using six items whose mean, median and standard deviation are shown in Table 3.

\section{Performance appraisal versus small- to medium- sized enterprises performance}

In assessing the impact of performance appraisal on performance, Spearman's correlation coefficient was used. The test was conducted under $\mathrm{H}_{1}$, which states that there is a statistically significant relationship between performance appraisal and firm performance measured by innovation.

Results from the test are summarised in Table 4.

The results displayed in Table 4 show a very weak negative $(-0.014)$ relationship between performance appraisal and firm performance as measured by innovation in the SMEs. Furthermore, the relationship is insignificant because of a $p$ value $(0.89)$, which is above 0.05 . The results suggest the acceptance of the null hypothesis; hence it can be concluded that there is no statistically significant relationship between performance appraisal and firm performance measured by innovation.

Spearman's correlation coefficient was again used to examine the nature and strength of the relationship between performance appraisal and firm performance as measured by ROI. The test was conducted under $\mathrm{H}_{2}$, which states that there is a statistically significant relationship between performance appraisal and firm performance measured by ROI. Results from the test are summarised in Table 5.

According to the results in Table 5, there is a very weak positive and statistically insignificant relationship between performance appraisal and firm performance as measured by ROI as the correlation coefficient value is 0.046 and the $p$ value is 0.636 (which is above 0.05 ). The results suggest the acceptance of the null hypothesis; hence we can as well conclude that there is no statistically significant relationship between performance appraisal and firm performance measured by ROI.

\section{Discussion of findings Performance appraisal methods}

Table 2 shows that most owner or managers made use of the 360-degree to appraise employees. A 360-degree feedback is based on multiple source evaluations. It provides an excellent opportunity for staff to express themselves without fear because of the anonymous nature of the review process. In family-run SMEs, 360-degree feedback helps validate the objectivity of feedback the family member receives, because the immediate supervisor is likely to include a range of viewpoints (Dashew 2007). It is highly likely that, as confirmed by Wood and Pereira (2014), although managers provided employees with feedback from colleagues and customers, there were no formal processes of 360-degree feedback systems within the enterprises. The aforesaid likelihood emanates from the absence of a HR department in a majority of the entrepreneurial ventures and the fact that owner or managers themselves run HRM issues (over 90\%). This suggests much informality in the appraisal process. The HR department would assist in creating a regulated organisational structure with justifiable grading and pay structures, promotion plans and employee compensation and benefit

TABLE 2: Performance appraisal methods.

\begin{tabular}{|c|c|c|c|c|c|}
\hline $\begin{array}{l}\text { Performance appraisal } \\
\text { methods items }\end{array}$ & Description & $N$ (Valid) & Mean & Median & Standard deviation \\
\hline PAM1 & $\begin{array}{l}\text { A 360-degree feedback using feedback from supervisors, team members, } \\
\text { customers, peers and self to rate employees. }\end{array}$ & 105 & 4.00 & 4.00 & 1.34 \\
\hline PAM2 & Rating performance against the achievement of agreed objectives. & 105 & 2.90 & 3.25 & 1.64 \\
\hline РАM3 & Using a grading system when rating employees. & 103 & 2.46 & 2.00 & 1.48 \\
\hline PAM4 & A cost and benefit analysis of keeping the employee. & 105 & 2.92 & 2.50 & 1.55 \\
\hline PAM5 & $\begin{array}{l}\text { Using a written record of critical incidents of favourable and highly unfavourable } \\
\text { employee work actions. }\end{array}$ & 106 & 2.57 & 2.50 & 1.58 \\
\hline PAM6 & Placing all employees from a group in rank order of overall performance. & 106 & 2.37 & 1.50 & 1.57 \\
\hline PAM & - & 105 & 2.87 & 2.63 & 1.53 \\
\hline
\end{tabular}


TABLE 3: Firm performance.

\begin{tabular}{lcccc}
\hline Variable & $N$ (Valid) & Mean & Median & $\begin{array}{c}\text { Standard } \\
\text { deviation }\end{array}$ \\
\hline SME Performance - Innovation & 106 & 3.88 & 4.00 & 0.624 \\
SME Performance - ROI & 103 & 3.62 & 3.84 & 0.730 \\
\hline
\end{tabular}

TABLE 4: Spearman's correlation on performance appraisal versus innovation.

\begin{tabular}{lllcc}
\hline Correlation & Variable & Test & $\begin{array}{c}\text { Performance } \\
\text { appraisal }\end{array}$ & Innovation \\
\hline Spearman's & Performance & Correlation coefficient & 1.000 & -0.014 \\
Rho & appraisal & Sig. (2-tailed) & - & 0.890 \\
& & $N$ & 106 & 106 \\
& Innovation & Correlation coefficient & -0.014 & 1.000 \\
& & Sig. (2-tailed) & 0.890 & - \\
& $N$ & 106 & 106 \\
\hline
\end{tabular}

TABLE 5: Spearman's correlation on performance appraisal versus return on investment.

\begin{tabular}{lllcc}
\hline Correlation & Variable & Test & $\begin{array}{c}\text { Performance } \\
\text { appraisal }\end{array}$ & ROI \\
\hline $\begin{array}{lllc}\text { Spearman's } \\
\text { Rho }\end{array}$ & Performance & Correlation Coefficient & 1.000 & 0.046 \\
& Appraisal & Sig. (2-tailed) & - & 0.636 \\
& \multirow{2}{*}{ ROI } & $N$ & 106 & 106 \\
& & Correlation Coefficient & 0.046 & 1.000 \\
& & Sig. (2-tailed) & 0.636 & - \\
& $N$ & 106 & 106 \\
\hline
\end{tabular}

ROI, return on investment

plans, amongst other numerous advantages (Umer 2012). The sheer lack of managerial capacity and culture in these firms results in managerial techniques (like performance appraisal) being perceived as of minimal benefit to the firm (Pekkola et al. 2016). Frequently, employees occupy several positions at the same time, organisational structures are flat, and though the owner or manager is in charge of both managerial and operational functions, managerial activities are usually neglected (Barisic \& Boricevic 2013).

Table 2 also shows that other performance appraisal methods like PAM 6-Rank ordering (mean = 2.37), on a Likert scale ranged from 1 Strongly Disagree to 5 Strongly Agree, were very unpopular. The reason could be that management practices in most SMEs are closely linked to the characteristics and skills of the entrepreneur, who usually will be multitasked and often takes on multiple roles (Ates et al. 2013). As a result, owner or managers hardly expand managerial practices further than the stage at which they can individually run everything themselves.

\section{Firm performance}

Table 3 shows that the firms performed fairly well in terms of both innovation and ROI. Product and process innovation (simply referred to as innovation in this study) initiatives are known to augment the long-term performance of a firm (Classen et al. 2014; Kraus, Harms \& Fink 2011). Innovations serve as major driving force for entrepreneurship at both firm and national levels (Kraus et al. 2011). However, the uptake of innovation could be tricky as innovation is a high-risk endeavour which involves large, upfront and mostly irreversible expenses, yet the success of innovations is not guaranteed (Classen et al. 2014). Interestingly, Matsotso and Benedict (2014) established that although purposively selected SMEs in manufacturing around Cape Town, South Africa, made use of non-financial performance measures and argue for their importance, the measures were not formally implemented. It was, however, beyond the scope of the current study to investigate this. Regarding innovation, a study by Mbizi et al. (2013) that sought to review the role of innovation in SMEs in the manufacturing sector of Chinhoyi, Zimbabwe, found that innovation was one of the major attributes that helped the SMEs remain competitive. They also established a strong link between innovation and the sustainability of SME operations (Mbizi et al. 2013). These results were also validated by Sandada and Mangwandi (2015), who confirmed innovation as one of the major factors affecting business performance in order of predictive power.

Concerning ROI, for any venture, whether large or small, family or non-family, profitability is crucial for it to remain a sound going concern (Lkhagvasuren \& Xuexi 2014). Compromises on profitability are likely to have adverse effects on both the capitalisation and expansion of a business. Profitability frequently measured by ROI has by convention been used to measure performance and is extensively regarded as the ultimate bottom line test of success (Farooq 2014). As a result, ROI becomes a very important measure that entrepreneurs can use, as it tells them the extent to which their investment has been a success (Lee 2012). In other words, ROI as a crucial balance sheet ratio helps in assessing the efficiency of the use of a business' resources as well as providing an indication of how effective one's investment in the business is (Lee 2012).

\section{Performance appraisal versus small- to medium- sized enterprises performance}

Results from the Spearman's correlation on performance appraisal versus SME performance showed very weak relationships between performance appraisal and firm performance measured by both ROI and innovation in the SMEs. Furthermore, the relationships were shown to be statistically insignificant because of $p$ values above 0.05 in both the cases. The results suggested the acceptance of the null hypotheses, thus concluding that there was no statistically significant relationship between performance appraisal and firm performance measured by both ROI and innovation.

According to the results, performance appraisal had no bearing on innovation or ROI. These results differ from those by Aleem and Rahman (2018), who examined the influence of $\mathrm{HR}$ practices on the perceived financial performance of listed SMEs in Karachi, Pakistan. Even though the study considered a bundle of HR practices, it confirmed that training and performance appraisal had the most positive and strongest association with a firm's perceived business performance. Results of the current study were again contrary to those of previous studies 
(Saunila 2014; Stanciu 2014), which established that performance management resulted in greater financial performance, innovation capability, increased employee productivity and more motivated employees in entrepreneurial ventures. In addition, this study's results again went contrary to those from a study of medium-sized enterprises in Sri Lanka by Wickramasinghe (2016). The study found that the following six characteristics of performance management, namely focus, target setting, integration with other HRM functions, administrative work procedures, interdependency and responsibility, were significant predictors of performance management effectiveness. The possible reason for failure by the SMEs investigated in the current study to reap benefits from performance appraisal could be that the firms used more informal management practices extensively, or they tried to adapt appraisal systems meant for large corporations, thereby negating the potential benefits brought by formality. Yet, increased use of formal employee appraisals is welcome because the establishment of an appraisal system represents the systematic collection of information about employees, which is the bedrock of all HR practice (Bach 2005). Consequently, cheap performance management software that focuses on individual needs of SMEs could be more ideal in the enterprises. Moreover, it would be better to use only a few vital indicators, especially if reported in a visually and graphically effective way, in order to allow the manager to concentrate only on crucial performance factors and to make informed decisions swiftly (Cocca \& Alberti 2010).

\section{Conclusions and recommendations}

The study established that the 360-degree method was the most popular performance appraisal method amongst owner or managers. It was found out that SMEs performed fairly well in terms of both innovation and ROI. Results from the Spearman's correlation on performance appraisal versus SME performance showed very weak relationships between performance appraisal and firm performance measured by both ROI and innovation in the SMEs. It was also concluded that there was no statistically significant relationship between performance appraisal and firm performance measured by both ROI and innovation.

Given the pivotal role SMEs play in the Zimbabwean economy, it is recommended that the government through the relevant ministries and agencies should consider more financial inducements, tax relief for start-ups and additional grants to support investment in new technology, and more training for owner or managers. Policies (like granting tax holidays) meant to incentivise large companies that finance SMEs could unlock much of the untapped funding. In addition, policies should be put in place to enable small-to-medium business owners access loans at concessionary interest rates. This could, amongst other things, go a long way in assisting them to acquire sufficient information technology infrastructure for supporting data collection, analysis, interpretation and reporting processes for effective implementation of performance appraisals.
Furthermore, the government should endeavour to ease the burdensome regulatory environment and associated bureaucracies that entrepreneurs need to go through, to register, formalise and professionalise operations. Stringent regulatory requirements may encourage shortcuts and informalisation, which may ultimately characterise the way performance appraisals will be executed in the firms. That could be done through crafting enabling policies that would enable owner or managers create platforms to not only voice their concerns but to make contributions regarding enactments of either trading laws, regulatory instruments or such other related enactments.

\section{Limitations and directions for future studies}

The majority of SMEs in Zimbabwe are informal, therefore very little information about the significance of their contribution to the economy (gross domestic product, employment levels, per capita income, exports, savings, investments, etc.) is properly appreciated (Mloyi 2011). Their informal nature often leads to the absence of business track records as most of them do not even bank their sales revenues. Related to this limitation was the issue of poor record keeping, which meant that participants had to rely on their memory for most of the information. In addition, as the study made use of cross-sectional data, future studies should strive to gather longitudinal data involving nation-wide samples in order to validate and enhance the generalisability of findings of the current study.

\section{Contributions of the study}

There is a dearth of studies that specifically consider performance appraisal in SMEs in Zimbabwe. In view of this, the current study is one of the very few, if any, that sheds light on the nexus between performance appraisal and the performance of SMEs in the country. In addition, the current investigation adopted a hybrid approach in the measurement of performance, making use of both an objective and more subjective measure - a digression from some school of thought that prefer use of objective measures only (Yildiz \& Karakas 2012).

\section{Acknowledgements}

The researcher would like to thank the research assistants former HRM students of Great Zimbabwe University who assisted in data collection.

\section{Competing interests}

The author declares that he has no financial or personal relationships that may have inappropriately influenced him in writing this article.

\section{Authors' contributions}

N.M. did problem formulation, data collection and review of literature. He also did data analysis and results and 
discussions sections. N.M also did the overall proofreading, editing and alignment of issues.

\section{Ethical consideration}

Ethical clearance has been provided by the Faculty Research and Innovation Committee in view of the CUT Research Ethics and Integrity Framework, 2016 with reference number 15/10/2015.

\section{Funding information}

This study was funded by the Research Board, Great Zimbabwe University, and the University Research and Innovation Committee, Central University of Technology, Free State, South Africa.

\section{Data availability statement}

Data for this study will be available upon reasonable request to the author.

\section{Disclaimer}

The views expressed in this article are not in any way an official position of the two aforementioned funding institutions but are entirely views of the concerned author.

\section{References}

Abduli, S., 2013, 'The role of human resources in performance management of SMEs: The case of Republic of Macedonia', International Journal of Academic Research in Business and Social Sciences 3(4), 223-236.

Aleem, M.U. \& Rahman, M., 2018, 'HRM practices and their impacts on the perceived performance of SME's operating in Karachi', Pakistan Business Review 40(2), 390-402.

Ates, A., Garengo, P., Cocca, P. \& Bititci, U.S., 2013, 'The Development of SME Managerial Practice for Effective Performance Management', Journal of Small Business and Enterprise Development 20(1), 28-54.

Arafat, M.A. \& Ahmad, E., 2012, 'Managing human resources in small and medium enterprises (SMEs) in developing countries: A research agenda for Bangladesh SMEs', International Proceedings of Economics Development and Research 55(43), 215-217.

Bach, S., 2005, 'New directions in performance management', in S. Bach (ed.), Managing human resources: Personnel management in transition, 4th edn., Blackwell Publishing, Oxford.

Barisic, A.F. \& Borisevic, M., 2013, 'Role of management consulting in a process of professionalisation of SME management', Učenje Za Poduzetništvo Entrepreneurial Learning 3(2), 144-160.

Bassioni, H.A., Price, A.D.F. \& Hassan, T.M., 2005, 'Theoretical formulation of a framework for measuring business performance in construction', viewed 31 August 2016, form http://www.irbnet.de/daten/iconda/CIB14664.pdf.

Biron, M., Farndale, E. \& Paauwe, J., 2011, 'Performance management effectiveness: Lessons from world-leading firms', The International Journal of Human Resource Management 22(6), 1294-1311. https://doi.org/10.1080/09585192.2011.559100

Bititci, U., Cocca, P. \& Ates, A., 2015, 'Impact of visual performance management systems on the performance management practices of organisations' International Journal of Production Research 54(6), 1571-1593. https://doi.org/1 International Journal of Production
0.1080/00207543.2015.1005770

Cardon, S.M. \& Stevens, E.C., 2004, 'Managing human resources in small organizations: What do we know', Human Resource Management Review 14(3), 295-323. What do we know', Human Resource Mand
https://doi.org/10.1016/j.hrmr.2004.06.001

Cardy, R., 2003, Performance management in SMEs, Managing Human Resources in Small, High Growth Companies, Columbus, $\mathrm{OH}$.

Chong, G.H., 2008, 'Measuring performance of small-and-medium sized enterprises: The grounded theory approach', Journal of Business and Public Affairs 2(1), 1-10.

Classen, N., Carree, M., Van Gils, A. \& Peters, B., 2014, 'Innovation in family and nonfamily SMEs: An exploratory analysis', Small Business Economics 42(3), 595-609. https://doi.org/10.1007/s11187-013-9490-z

Cocca, P. \& Alberti, M., 2010, 'A framework to assess performance measurement systems in SMEs', International Journal of Productivity and Performance Management 59(2), 186-200. https://doi.org/10.1108/17410401011014258

Cohen, L., Manion, L. \& Morrison, K., 2011, Research methods in education, 7th edn. Routledge, London.
Creswell, J.W., 2012, Qualitative inquiry \& research design: Choosing among five approaches, 4th edn., Sage, Thousand Oaks, CA.

Dashew, L., 2007, 'Performance management systems should include family employees', viewed 13 April 2016, from http://www.lesliedashew.com/_assets/ pdf/articles/performance-management-systems.pdf.

De Kok, J.M.P., Thurik, A.R \& Uhlaner, L.M., 2003, Human Resource Management with Small Firms; Facts and Explanations., Paper provided by Erasmus Research Institute of Management (ERIM), Rotterdam, Netherlands.

DeNisi, A.S., 2011, 'Managing performance to change behaviour', Journal of Organizational Behaviour Management 31(4), 262-276. https://doi.org/10.1080/ 01608061.2011.619414

DeNisi, A.S. \& Murphy, K.R., 2017, 'Performance appraisal and performance management: 100 years of progress?', Journal of Applied Psychology 102(3), 421433. https://doi.org/10.1037/apl0000085

Dessler, G., 2013, Human resource management, 13th edn., Pearson Education, Boston, FL.

De Vos, A.S., Strydom, H., Fouché, C.B. \& Delport, C.S.L., 2011, Research at grassroots: For the social sciences and human services professions, 4th edn., Van Schaik Publishers, Cape Town.

Economist Intelligence Unit (EIU), 2010, SMEs in Japan: A New Growth Driver?, viewed 02 November 2017, from http://viewswire.eiu.com/report_dl.

Farooq, R., 2014, 'A clever approach to measure organisational performance: An overview', Indian Journal of Management 7(5), 34-46. https://doi. org/10.17010//2014/v7i5/59321

Forth, J. \& Bryson, A., 2018, The impact of management practices on SME performance, Discussion Paper Series, IZA Institute of Labour Economics, DP No. 11399, pp. $1-38$.

Foss, N.J., Pedersen, T., Reinholt, F.M. \& Stea, D., 2015, 'Why complementary HRM practices impact performance: The case of rewards, job design, and work climate in a knowledge-sharing context', Human Resource Management 54(6), 955-976. in a knowledge-sharing context', Humat
https://doi.org/10.1002/hrm. 21649

Garengo, P., Biazzo, S., \& Bititci, U.S., 2005, 'Performance measurement systems in SMEs: A review for a research agenda', International Journal of Management Reviews 7(1), 25-47. https://doi.org/10.1111/j.1468-2370.2005.00105.x

Gravetter, F.J. \& Forzano, L.A.B., 2016, Research methods for the behavioural sciences, 5 th edn., Wadsworth Cengage Learning, Belmont, CA

Gravina, N.E. \& Siers, B.P., 2011, 'Square pegs and round holes: Ruminations on the relationship between performance appraisal and performance management', Journal of Organisational Behaviour Management 31(4), 277-287. https://doi.or $\mathrm{g} / 10.1080 / 01608061.2011 .619418$

Hair, J.F., Black, W.C, Babin, B.J. \& Anderson, R.E., 2014, Multivariate Data Analysis, 7 th ed, Edinburgh Gate, Pearson Education Limited.

Harney, B. \& Nolan, C., 2014, 'HRM in small and medium-sized firms', in B. Harney \& K. Monks (eds.), Strategic HRM: Research and practice in Ireland, Orpen Press, Dublin, 153-169.

Heinicke, A., 2018, 'Performance measurement systems in small and medium-sized enterprises and family firms: A systematic literature review', Journal of Management Control 28(4), 1-46. https://doi.org/10.1007/s00187-017-0254-9

Hoskisson, R., Eden, L., Lau, C.M., \& Wright, M., 2000, 'Strategy in emerging economies', Academy of Management Journal 43(3), 249-267.

HR Tool, 2011, Performance Management and Appraisal, viewed 15 May 2019 from https://pdfs.semanticscholar.org/93cc/62d7f8a9188c88c509df80b6550f98bc5e 7f.pdf

Hughes, C., 2006, 'Qualitative and quantitative approaches to social research', viewed 24 February 2014, from http://www2.warwick.ac.uk/fac/soc/sociology/staff/ hughes/researchprocess/quantitative_and_qualitative_approaches.docx.

Ilgen, D.R, Barnes-Farrell, J.L, Mckellin, D.B, 1993, 'Performance appraisal process research in the 1980s: What has it contributed to appraisals in use?', Organizationa Behavior and Human Decision Processes 54, 321-368.

Jamsari, B.A., Mahmood, N.H.N. \& Raghavan, S., 2017, 'The determinant of employee job performance: Incorporating Malaysian SME's experience on recruitment', Medwell Journals, The Social Sciences 12(1), 39-42.

Juneja, P., 2019, 'Evolution of performance management', viewed 11 November 2018, from https://www.managementstudyguide.com/performance-managementevolution.htm.

Kamoyo, M., Muranda, Z. \& Mavhima, F., 2014, 'Cluster approach to microenterprise development: A comparative study of clustered and isolated wooden furniture enterprises in Zimbabwe, Journal of Sustainable Development in Africa 16(5), 14-32.

Kasperskaya, Y. \& Tayles, M., 2013, 'The role of causal links in performance measurement models', Managerial Auditing Journal 28(5), 426-443. https://doi. org/10.1108/02686901311327209

Khahan, N., 2016, 'Performance management for small and medium enterprises (SMEs) in Thailand', International Journal of Economic Research, Serials Publications 13(14), 1641-1658.

Kim, Y. \& Gao, F.Y., 2010, 'An empirical study of human resource management practices in family firms in China', The International Journal of Human Resource Management 21(2), 2095-2119. https://doi.org/10.1080/09585192.2010.509619

Kraus, S., Harms, R. \& Fink, M., 2011, 'Family firm research: Sketching a research field', International Journal of Entrepreneurship \& Innovation Management 13(1), 32-47. https://doi.org/10.1504/IJEIM.2011.038446

Lee, B., 2012, Financial guide for small and medium enterprises, CPA Australia Ltd, Singapore. 
Lkhagvasuren, T. \& Xuexi, H., 2014, 'Analysis of the returns of small and medium-sized enterprises in Mongolia', Journal of Finance and Accounting 2(3), 41-47. https:// enterprises in Mongolia', Journal of
doi.org/10.11648/j.jfa.20140203.12

Luebker, M., 2008, 'Employment, unemployment and informality in Zimbabwe: Concepts and data for coherent policy-making', Issues paper No. 32 and integration working paper No. 90, ILO Sub-Regional Office for Southern Africa (SRO-Harare) Harare and Policy Integration and Statistics Department International Labour Office, Geneva.

Madzivanzira, A., 2011, 'SMEs key to economic recovery', The Patriot, viewed 01 June 2016, from http://www.thepatriot.co.zw/old_posts/smes-key-to-economicrecovery/.

Mathis, R.L. \& Jackson, J.H., 2005, Human resource management, 12th edn., Thomson South-Western, Mason, $\mathrm{OH}$.

Matsotso, M.L. \& Benedict, H.O., 2014, 'Non-financial performance measures in small medium enterprises' supply chain management', Journal of Economics 5(3), 247-257. https://doi.org/10.1080/09765239.2014.11885001

Mbizi, R., Hove, L., Thondhlana, A. \& Kakava, N., 2013, 'Innovation in SMEs: A review of its role to organisational performance and SMEs operations sustainability', Interdisciplinary Journal of Contemporary Research in Business 4(11), 370-389.

Mckenna, E. \& Beech, N., 2013, Human resource management: A concise approach, 3rd edn., Prentice Hall, London.

McMahon, G., 2013, 'Performance management in human resource management', in R. Carbery \& C. Cross (eds.), Human resource management, Palgrave Macmillan, Dublin, 769-787.

Melo, P.R.N. \& Machado, C.F., 2014, 'Human resource management evolution in SMEs: Recruitment and selection case', in C. Machado \& P. Melo (eds.), Effective huma resources management in small and medium enterprises: Global perspectives, Advances in Human Resource Management and Organisational Development Book Series, Business Science Reference, IGI-Global, pp. 377-392, Hershey.

Memon, S.B., Rohra, C.L. \& Lal, P., 2010, 'Critical analysis of the performance management system (PMS) in SMEs of Karachi', Australian Journal of Basic and Applied Sciences 4(6), 1495-1503.

Ministry of Finance, 2011, Budget Statement As Presented by Finance Minister Tenda Biti in Parliament, viewed 03 February 2018, from http://archive.kubatana.net/ $\mathrm{html} /$ archive/econ/101125minfin.asp\#download

Mloyi, N., 2011, 'The challenges faced by small enterprises in Zimbabwe: A search for lasting solutions', viewed 01 June 2016, from https://milliondolla.wordpress. com/2011/11/02/it-is-well-know/.

Na-Nan, K., Chaiprasit, K. \& Pukkeeree, P., 2017, 'Performance management in SME high growth sectors and high-impact sectors in Thailand: Mixed method research', high growth sectors and high-impact sectors in Thailand: Mixed method research',
International Journal of Engineering Business Management 9(4), 1-9. https://doi. International Journal of Engineering
org/10.1177/1847979017718451

Neneh, N.B. \& Van Zyl, J.H., 2012, 'Achieving Optimal Business Performance through Business Practices: Evidence from SMEs in Selected Areas in South Africa', Southern African Business Review 16(1), 118-144.

Neuman, W.L., 2011, Social research methods: Qualitative and quantitative approaches, 7th edn., Pearson Education, Boston, MA.

Nguyen, T.V. \& Bryant, S.E., 2004, 'A study of the formality of human resource management practices in small and medium-size enterprises in Vietnam International Small Business Journal 22(6), 595-618. https://doi.org/10.1177/ 0266242604047412

Noe, R.A., Hollenbeck, J.R., Gerhart, B. \& Wright, P.M., 2015, Human resource management: Gaining a competitive advantage, 9th edn., Mcgraw Hill, New York, NY

Nongmaithem, R.S. \& Kassa, B., 2016, 'The impact of human resource management practice on organizational performance - A study on Debre Brehan University', International Journal of Recent Advances in Organizational Behaviour and Decision Sciences 1(1), 643-662.

Nzonzo, C.J. \& Matashu, M., 2014, 'An Insight Into The Human Resource Management Practices Adopted By Entrepreneurs In South Africa', Journal Of Small Business And
Entrepreneurial Development 2(3\&4), 73-87. http://dx.doi.org/10.15640/jsbed. Entrepren
$\mathrm{v} 2 \mathrm{n} 3-4 \mathrm{a} 5$

Obasan, K.A., 2012, 'The impact of understanding human resources management on small business performance in Nigeria: An empirical juxtaposition', International Journal of Business and Management Tomorrow 2(2), 456-564.

Oduro-Nyarko, C., 2013, 'Assessment of performance appraisal techniques by small and medium size hotels in Central Ayawaso Metropolitan Area developing country studies', Developing Country Studies 3(12), 9-15, viewed 23 March 2018 from www.iiste.org.

OECD, 2014, 'Corporate governance of small and medium-sized enterprises (SMEs)', viewed 06 November 2016, from http://www.oecd.org/daf/ca/ corporategovernanceofstateownedenterprises/corporategovernanceofsmalland medium-sizedenterprisessmes.htm.

Ogiogio, G., 2005, 'Measuring performance of interventions in capacity building Some fundamentals', The African Capacity Building Foundation. The African Capacity Building Foundation Occasional Running Paper No. 4, Harare, pp. 1-21.

Panda, S., 2011, 'Performance management system: Issues and challenges', Management And Labour Studies 36(3), 271-280. https://doi.org/10.1177/0258042X1103600304

Patel, P.C. \& Cardon, M.S., 2010, 'Adopting HRM practices and their effectiveness in small firms facing product-market competition', Human Resource Management 49(2), 265-290. https://doi.org/10.1002/hrm.20346
Pekkola, S., Saunila, M. \& Rantanen, H., 2016, 'Performance measurement system Implementation in a turbulent operating environment', International Journal of Productivity \& Performance Management 65(7), 947-958. https://doi. Productivity \& Performance
org/10.1108/IJPPM-01-2015-0018

Peng, M.W., 2001, 'How entrepreneurs create wealth in transition economies', Academy of Management Executives 15(1), 95-108.

Prasad, L.M., 2006, Human resource management, Sultan Chand \& Sons: Educational Publishers, New Delhi.

Punch, K.F., 2005, Introduction to social research: Quantitative and qualitative approaches, 2nd edn., Sage, Los Angeles, CA.

Reid, R.S. \& Adams, J.S., 2001, 'Human resource management - A survey of practices within family and non-family firms', Journal of European Industrial Training 25(6), 310-320. https://doi.org/10.1108/03090590110401782

Saha, N., Gregar, A. \& Sáha, P., 2017, 'Organizational agility and HRM strategy: Do they really enhance firms' competitiveness?', International Journal of Organisational Leadership 6(3), 323-334. https://doi.org/10.33844/ijol.2017.60454

Sandada, M. \& Mangwandi, L., 2015, 'An assessment of the influence of selected SMEs on the performance of small to medium sized family owned businesses in the Zimbabwe retail sector', Audoe 11(5), 5-16.

Sandada, M., 2012, 'Strategic planning and its relationship with the performance of small and medium-sized enterprises in Gauteng', Doctoral thesis, Faculty of Management Sciences, Vaal University of Technology.

Saunders, M., Lewis, P. \& Thornhill, A., 2009, Research methods for business students, 5th ed., Prentice Hall, London.

Saunila, M., 2014, 'Understanding innovation performance measurement in SMEs', Measuring Business Excellence 21(1), 1-16. https://doi.org/10.1108/MBE-012016-0005

Sidhardth, P., 2011, 'Strategic mapping for dynamic performance for HR competencies', viewed 15 May 2018, from http://www.google.co.zw/url?url=http://shodhganga. inflibnet.ac.in/bitstream.

Simon, M.K. \& Goes, J., 2011, 'Correlational research', viewed 29 April 2019, from www.dissertationrecipes.com.

Southern Eye, 2014, SMEs Drive Economy: Nyoni, viewed 03 February 2018 from https://www.southerneye.co.zw/2014/11/18/smes-drive-economy-nyoni/

Stanciu, R.D., 2014, 'Do Romanian small and medium-sized enterprises use performance management? An empirical study', Procedia Social and Behavioural Sciences 124, 255-262, viewed 15 June 2019, from www.sciencedirect.com.

Taticchi, P., Tonelli, F. \& Cagnazzo, L., 2010, 'Performance measurement and management: A literature review and a research agenda', Measuring Business Excellence 14(1), 4-18. https://doi.org/10.1108/13683041011027418

Taylor, F.W., 1911, The principles of scientific management, Harper \& Brothers, New York, NY.

Toppo, L. \& Prusty, T., 2012, 'From performance appraisal to performance management', IOSR Journal of Business and Management 3(5), 1-6. https://doi. org/10.9790/487X-0350106

Tripathi, P.C., 2006, Human resource development, Sultan Chand \& Sons: Educational Publishers, New Delhi.

Umer, M. 2012, 'Human resource management theory and practices in small and medium-sized enterprises (SMEs) and enterprises performance in Pakistan' Global Journal of Management and Business Research 12(13), 28-44.

Van Riemsdijk, M.J., Bondarouk, T. \& Knol, H., 2005, 'Researching personnel management in Dutch small and medium sized enterprises', Paper Presented at the 4th International Conference of the Dutch HRM Network, 4-5 November 2006, Enschede, pp. 309-319.

Wickramasinghe, V., 2016, 'Performance management in medium-sized enterprises', Performance Improvement Quarterly 29(3), 307-331. https://doi.org/10.1002/ piq. 21227

Wijetunge, W.A.D.S., 2014, 'Strategic planning practices of manufacturing small and medium scale enterprises in Sri Lanka: An empirical study', Global Journal of Commerce \& Management Perspective 3(6), 102-109.

Wood, J. \& Pereira, V., 2014, 'A case study of performance appraisal in a SME: Moving on from the tick-box generation', HR Bulletin: Research and Practice 9(1), 23-30.

Yildiz, S. \& Karakas, A., 2012, 'Defining methods and criteria for measuring business performance: A comparative research between the literature in Turkey and foreign', Procedia Social and Behavioural Sciences 58, 1091-1102, viewed 30 December, 2019, from https://pdf.sciencedirectassets.com/.

Zehir, C., \& Acar, A.Z., 2005, 'The Effects of Organizational Competences on Business Performance, Gazi University', The Journal of Economics and Administrative Sciences Faculty 7(3), 15-34.

Zheng, C., O'Neill, G. \& Morrison, M., 2009, 'Enhancing Chinese SME performance through innovative HR practices', Personnel Review 38(2), 175-194. https://doi. org/10.1108/00483480910931334 